\title{
Espaço, Tempo e Narrativas: reflexões sobre a cultura Inỹ/Javaé, Ilha do Bananal, Tocantins, Brasil
}

\author{
Odair Giraldin ${ }^{1}$ \\ Ricardo Tewaxi Javaé ${ }^{2}$
}

${ }^{1}$ Universidade Federal do Tocantins, Campus de Porto Nacional, TO, Brasil

${ }^{2}$ Escola Indígena Tainá, Ilha do Bananal, Formoso do Araguaia, TO, Brasil

\section{Resumo}

Este artigo trata de reflexões sobre a cosmografia Inỹ/Javaé e sua relação com o ambiente da Ilha do Bananal, no Estado do Tocantins, Brasil. A via utilizada para tal reflexão são as narrativas sobre as relações estabelecidas entre os diversos povos que deram origem aos Inỹ/Javaé atuais, partindo do princípio da relação intersubjetiva e dos elos narrativos que constroem o conhecimento do ambiente por meio das sensibilidades e habilidades elaboradas ao longo do tempo.

Palavras-chave: Ambiente. Narrativas. Histórias.

\section{Space, Time and Narratives: reflection on Inỹ/Javaé culture, Bananal Island, Tocantins, Brazil}

\begin{abstract}
This article approach the reflection about the cosmography of the Iny/Javaé people and its relations with the environment of Bananal Island, at Tocantins state, Brazil. The way do that are the narratives about the relationships established between the various peoples that originated the present Iny//Javaé, based on the principle of intersubjective relationship and the narratives nexus that builds knowledge of the environment through the sensibilities and skills realized over time.
\end{abstract}

Keywords: Environment. Narratives. Histories. 


\section{Introdução}

$\mathrm{O}$ elo que faz a ligação entre as coisas do mundo e as tornam significativas para alguém depende da experiência, da vivência e dos sentimentos da pessoa ao longo de sua vida na interação com o ambiente. Isso significa dizer que não há um conjunto de elementos a serem conhecidos separados do sujeito conhecedor, de tal maneira que a aquisição do conhecimento dar-se-ia pela paulatina apropriação dos elementos do conjunto a ser conhecido. A produção do conhecimento dá-se pelo processo de contínua interação dos sujeitos cognocentes com os elementos transformacionais que compõem o ambiente em que vivem, sendo esse um processo histórico (porque contínuo) e repleto de relações intersubjetivas. Esse processo histórico de apreensão do ambiente (mundo experimentado) é o que Tim Ingold chama de "ecologia sensível", cujo conhecimento "[...] baseia-se no sentimento, consistindo nas habilidades, sensibilidades e orientações que se desenvolveram através da longa experiência de conduzir a vida de alguém em um ambiente específico" (INGOLD, 2000, p. 25). Esse conhecimento não está ligado apenas a um processo de transmissão textual entre duas pessoas, mas sim ao processo de experimentação do ambiente que somente se processa pela convivência prática. Por isso, a importância da mobilidade e das atividades práticas como parte do processo de "educação da atenção" (GIBSON, 1979, apud INGOLD, 2000, p. 22), por meio do qual uma geração pode proporcionar à geração seguinte o contato com os elementos que compõem o cosmos através da experimentação das sensações, como a visão, olfato, sabor, sentimentos.

É com essa característica que apresentamos as descrições e reflexões sobre o longo processo histórico de vivência dos Inỹ/Javaé com a Ilha do Bananal, a maior ilha fluvial do planeta, formada pela divisão do rio Araguaia, na divisa dos Estados do Tocantins, Mato Grosso e Pará, na região central do Brasil. Com área de aproximadamente de 25 mil km², parte da ilha é ocupada pela Terra Indígena Parque do Araguaia, que abrange toda a porção sul e boa parte da porção oeste da Ilha do Bananal, seguindo a calha do rio Araguaia e ocupada principalmente pelos Inỹ/Karajá. Há também o Parque Nacional do Araguaia, que abrange as porções norte e nordeste da ilha, além da Terra Indígena Inãwébohona, que se sobrepõe ao Parque Nacional do Araguaia, que está localizada na porção nordeste da ilha, e a Terra Indígena Utaria Wyhyna/Iròdu Iràna, que também se sobrepõe ao Parque Nacional do Araguaia e está localizada na porção norte da ilha ${ }^{1}$. Além dos povos Inỹ/Javaé e Inỹ/Karajá, também o povo Avá-Canoeiro, que ocupava áreas adjacentes à Ilha do Bananal, quando foram forçadamente contatados em 1973, hoje

Consultar https://pt.wikipedia.org/wiki/Ilha_do_Bananal\#cite_note-Itam-5. 
habitam em aldeias dentro do território da Ilha do Bananal. Atualmente há registros da presença dos Avá vivendo autonomamente nas matas no interior da ilha. Ao norte da ilha, vivem também grupos de Tapirapé e grupos resultantes de miscigenação destes com os Karajá.

Os povos Inỹ falam variações dialetais da língua Inỹribe, da família linguística Karajá e do Tronco Macro-Jê. Os Avá-Canoeiro e os Tapirapé falam línguas da família linguística Tupi-Guarani do Tronco Tupi.

Além de uma "ecologia sensível", do mundo da vida (INGOLD, 2000, p. 14), as narrativas, as descrições espaciais e as reflexões aqui apresentadas nos proporcionam também a compreensão da cosmografia do povo Inỹ/Javaé, ou seja, a maneira como se descrevem as experiências, as atividades e os contatos imediatos que compõem o mundo de uma vida individual ou coletiva, na forma como a define Paul Little (2003, p. 254):

[...] como os saberes ambientais, ideologias e identidades - coletivamente criados e historicamente situados - que um grupo social utiliza para estabelecer e manter seu território. A cosmografia de um grupo inclui seu regime de propriedade, os vínculos afetivos que mantém com seu território específico, a história da sua ocupação guardada na memória coletiva, o uso social que dá ao território e as formas de defesa dele.

As descrições e narrativas históricas apresentadas aqui estão articuladas em um tipo de "elo narrativo" (BASSO, 2000, p. 296) que interliga experiências passadas com acontecimentos atuais, que nos levam a compreender tanto o processo histórico (do ponto de vista ocidental) da ocupação memorial do lugar chamado Ilha do Bananal quanto as relações estabelecidas entre os diferentes povos Inỹ dos quais os Javaé atuais são os descendentes. Tal "elo narrativo" é elemento importante e fundamental para a apreensão dos espaços e para sua legitimação como lugares de vida.

A compreensão da ocupação e o uso do território pelos Inỹ/Javaé se interligam num complexo de narrativas que se inicia com a ascensão dos humanos primordiais a partir do mundo existente no nível subaquático e depois se alongam em inúmeros elos que explicitam como os elementos do mundo foram sendo transformados. Nesses elos, também estão interligadas as relações que se deram entre os diversos povos que ascenderam, que levam os Inỹ/Javaé a serem considerados o "povo do meio", tanto no sentido de estarem no nível do meio do mundo (em oposição ao nível subaquático e aos níveis celestes) quanto no sentido de ser um povo resultante de transformações culturais advindas do fato de viverem no "meio" dos outros povos².

Os resultados aqui apresentados se originaram de pesquisas que são frutos de estudos aprofundados por Ricardo Tewaxi Javaé em três momentos. Inicialmente por ser membro de uma família cujos membros mantiveram a memória de seu povo, Tewaxi cresceu e foi sendo preparado para ser também um historiador do seu povo. Nos anos 1980, a presença dos não indígenas e suas agências entre os Javaé não era tão intensa. Assim, Tewaxi quando era jovem, foi participando das atividades culturais tradicionais que aconteciam com frequência e, ao mesmo tempo, aprendendo as narrativas sócio-históricas Inỹ/Javaé

2 Para essas narrativas e a cosmografia Inỹ/Javaé, os trabalhos de Patrícia Mendonça Rodrigues (1993; 2008) são absolutamente fundamentais. Ver também o artigo "Rede de histórias dos povos que deram origem ao povo Inỹ/Javaé" de Giraldin e Javaé (2019). 
apenas pela oralidade. Nesse período pré-universalização da escolarização entre os povos indígenas, provocado pelo Decreto n. 26, de 4 de fevereiro de 1991, as ocupações dos jovens se davam majoritariamente com as atividades culturais tradicionais.

Posteriormente, com seu ingresso no curso superior em Educação Intercultural na Universidade Federal de Goiás em 2009, a dedicação foi na ampliação desses estudos, voltando-os para sua aplicabilidade na escola indígena, como parte das atividades de formação docente. Agora, já num contexto de universalização do acesso à educação escolar, os jovens passam boa parte do seu tempo em atividades vinculadas às questões escolares. Nesse sentido, a escolarização crescente exige dos jovens concentração e foco na escrita e na aprendizagem escolar, subtraindo-os da possibilidade de concentrar-se em ouvir e em memorizar as narrativas tradicionais.

Com esse processo de contato intenso com os não indígenas e o crescimento da escolarização, os pais veem na educação escolar não indígena um caminho para que os filhos possam conseguir emprego e alguma renda, em atividades praticadas a partir do contato com não indígenas. Apesar de se tratar de narrativas orais, cujos conteúdos são muito mais expressivos quando contemplam toda as nuances e possibilidades dadas pela oralidade, atualmente há uma tendência de predomínio da escrita sobre a oralidade, atribuindo-se então um papel central da escola e da escrita no processo de preservação da memória. Sem tempo e sem acesso aos anciãos narradores orais, os jovens podem acessar esse conhecimento, ainda que com as limitações da fixação escrita, por meio das escolas e dos livros e materiais didáticos.

Assim, finalmente o terceiro momento de aprofundamento destas pesquisas foi quando houve a oportunidade para a realização de pesquisas mais acuradas sobre a ocupação da Ilha do Bananal, tendo como foco o rio Javaés, abordado como um lugar socialmente construído, como argumenta Tuan (1983) no Programa de Pós-Graduação em Ciências do Ambiente na Universidade Federal do Tocantins. Foi então que houve a contribuição de Odair Giraldin na orientação e, posteriormente, na redação compartilhada do presente artigo.

Vivenciamos nesse processo de produção intelectual uma parceria profícua e, em certo sentido, uma relação simétrica entre os autores. Com isso, a opção de evitar uma apropriação colonialista do conhecimento detido pelo membro do povo indígena, utilizando-o em proveito da autoria do pesquisador não indígena. Enquanto um possui uma bagagem mais teórica do campo antropológico, o outro detém todo o conhecimento elaborado, preservado e transmitido ao longo de gerações de narradores.

A coautoria busca, então, estabelecer uma relação simétrica entre os dois mundos e suas respectivas formas de abordagens desses mundos. Um autor, como historiador e antropólogo com formação acadêmica científica, procura descentrar-se para escutar e compreender o mundo visto e descrito nas narrativas e nas interlocuções. O outro, historiador formado por meio da escuta da oralidade e agora também um pesquisador sobre o seu povo Inỹ/Javaé. Ambos os autores, ao compartilharem suas experiências e conhecimentos, buscam oferecer um texto que se adeque e esse novo momento de vivência intelectual em que o lugar de fala do não indígena não é o único no processo de escrita do texto. Desejamos que este artigo seja lido dentro dessa sua característica que busca colocar ambos os conhecimentos em paralelo. Escrever é um ato também político. 
Este artigo está composto de duas partes. Na primeira são apresentadas as narrativas sobre as aldeias e os lugares mais significativos na história Inỹ/Javaé, pela qual se explicitam tanto os elos narrativos quanto a cosmografia daquele povo no ambiente em que vivem. A segunda parte inicia-se com a chegada dos tori (não indígenas) e tece reflexões sobre a situação cultural dos Inỹ/Javaé desde as práticas que ocorriam no passado quanto aquelas que se dão no presente.

\section{O Povo Kuratanikèhè de Marani-Hawa}

Historicamente, o lugar era da Dimaraniru, nome de uma mulher que morou nesse lugar, que acabou sendo chamado de Marani-Hawa, pois do nome Dimaraniru contraiu para marani enquanto hawa significa lugar. Esse povo era o mais populoso da Ilha do Bananal e ficava no meio dos outros povos indígenas que não eram Inỹ. Ao redor do lugar de Marani-Hawa (número 16 no mapa adiante) tinham outros ixyju (não Inỹ), por isso que era chamado de ixyju-tya mahadu, derivando o nome de ixyju mahadu (povos não Inỹ). Existia o iòlò na cultura do povo Kuratanikèhè. Iòlò Tòlòra, Iòlò Haruèsi, Iòlò Timyjuy eram os iòlò dos povos de Kuratanikèhè, sendo que eles são considerados os grandes iòlò e, por isso, muito respeitados pelos outros povos indígenas da Ilha do Bananal. O lugar Marani-hawa fica no sul da Ilha do Bananal, de onde saíram as bananas nativas, sendo que ainda hoje naquele lugar existe um bananal nativo.

O hábito alimentar do povo Kuratanikèhè estava ligado ao consumo de peixe-elétrico e de animais como macaco-guariba, além do pássaro mergulhão. Esse povo tinha o costume tradicional de realizar acampamentos no interior da ilha, nas margens do Riozinho (Worosy-bero), nas margens de rio Jaburu (Ikorobi-wo) e no rio Javaés. Os povos iam caminhando aproximadamente $18 \mathrm{~km}$ desde o Riozinho para chegar ao rio Javaés. As mulheres carregavam as suas bagagens nos balaios (wèriri) e os homens nos cestos chamados de bèhyra.

Com suas canoas, eles subiam ou desciam no rio Javaés. Algumas famílias iam até o rio Araguaia, nos tempos de tartarugas desovar nas praias, de onde voltavam para sua aldeia de origem. Descendo o rio Javaés, iam até Kanõanõ (número 19 no mapa) onde pegavam os cocos babaçu e tiravam os iambe (tytè $)^{4}$ para fazer suas flechas. Em todos os períodos do ano, os lugares de pesca e as praias do rio Javaés eram frequentados pelos povos indígenas Inỹ/Javaé. Mesmo na estação seca, os povos navegavam e buscavam as tartarugas nas praias. Só que não passavam muitos dias na região da atual aldeia de Kanõanõ, porque lá existiam os Ava-Canoeiro5. Mas quando era o tempo de enchente, os

\footnotetext{
3 Este conselheiro formal da comunidade (Ioló) é um título e uma função repassados patrilateralmente de pai para filho primogênito. Em caso de o primogênito ser do sexo feminino, ela poderá receber este título e função cerimonial. Mas ela deverá transmitir essa condição para seu filho primogênito. Tòlòra era grande iòlò de Ilha do Bananal, por isso que existem os iòlò nas culturas dos povos Inỹ/Javaé. Iòlò Haruèsi também há seus descendentes nos povos da Ilha do Bananal, como também há os descendentes do iòlò Timyjuy. Assim os descendentes dos primeiros iòlò se espalharam na Ilha do Bananal. Meus avós paternos (do ponto de vista de Tewaxi, coautor deste artigo) são descendentes dos Wèrè e meus avós maternos são descendentes de Kuratanikèhè e do ioló Haruèsi. Minha sobrinha-neta (do ponto de vista de Tewaxi, coautor deste artigo) é a ioló atual, descendente do ioló Haruèsi.

4 Tytè é uma embira retirada de entrecasca da árvore landi usada para enrolar e amarrar as flechas e também para fazer enfeites e adornos, como o cocar.

5 Povo de língua Tupi-Guarani que viveu autonomamente durante muito tempo dentro da Ilha do Bananal. Sobre eles, ver Pedroso (1992) e Rodrigues (2013).
} 
povos de três aldeias (os povos de Marani-Hawa, povos de Imõtxi (número 24 no mapa) e os povos de Wari-Wari (número 31 no mapa) chegavam sem receio de encontrar com os Avá-Canoeiros para tirar os recursos naturais dos lugares, como o tytè, uma vez que, nestas condições, aquele povo permanecia nas partes não alagadas da região.

O povo Kuratanikèhè acampava também nas margens de rio Jaburu (Ikorobi wo). Eles iam a pé e buscavam os ovos de tartarugas no mês de outubro (kòtuni-si, ahadu). Era também costume tradicional de Marani-Hawa mahadu matar os pássaros como os colhereiros (wararè), nos ninhais (nawakikòna) para tirar as penas das asas usadas em suas flechas (wyhy). Dos jaburus (waruri), eles tiravam as penas de asas tanto para colocar nas suas flechas quanto para fazer seus cocares (raheto). As penugens eram usadas para enfeitar o corpo, colando elas nos braços e nas pernas. Quando acontecia de irem atacar os pássaros nos ninhais, os hàri (xamãs) e os homens faziam a cerimônia de calugi ${ }^{6}$, chamado bètò ${ }^{7}$, para servir como oferenda ao espírito de aruanã ${ }^{8}$, que é o dono das ninhadas dos pássaros naquele lugar, objetivando com isso evitar que acontecesse algum acidente com eles. Depois que terminavam o ritual de bètò (cuja participação é exclusivamente masculina), os homens começavam a flechar os pássaros nas ninhadas. Algumas mulheres e as crianças iam para lá pegar os filhotes de colhereiros.

Todos os anos os povos caçavam os pássaros colhereiros nos ninhais, no local atualmente chamado de Bebedor, onde existiam e ainda existem as ninhadas desses pássaros. Da mesma forma, quando tivesse muitos peixes, como as piabanhas ou pirarucus em algum lago ou no rio, os hàri já entendiam qual espírito de aruanã que ali existia, que eram moradores e donos desses lugares. E para pescar no local, faziam também o mesmo ritual bètò. O mesmo eles faziam antecedendo as atividades de pescarias de tartarugas. Esse bètò era feito para os espíritos de aruanãs não ficarem bravos.

Os patos selvagens também têm seu dono, que é algum espírito de aruanã, mas para caçá-los não faziam o ritual de cerimônia bètò. Os homens, cada um individualmente, faziam xiwè em casa. Cada um fazia esse tipo de xiwè, pedindo para os espíritos de seus parentes ajudarem para evitar a ocorrência de algo ruim e para matar os patos. Somente depois é que iam esperar os patos selvagens nas matas.

Para as caçadas dos porcos queixadas $(i x \tilde{y})$, os homens faziam primeiro xiwè na casa dos homens (casa de aruanã) e depois seguiam atrás dos porcos queixadas. Quando os homens chegavam da caçada, o que acontecia na tarde do outro dia, todos levavam os seus xiwè, as oferendas (carne das caças conseguidas) para os espíritos dos seres humanos e espíritos de aruanã que estavam na casa dos homens. Há um xiwè feito separadamente para Tori-kuni (espírito de não índio), uma oferenda para o espírito de homem branco, que é o maior protetor dos povos indígenas Inỹ/Javaé da Ilha do Bananal. O espírito de homem branco não deixa os porcos queixadas saírem dos lugares sendo facilmente

\footnotetext{
Bebida fermentada feita à base de mandioca, batata-doce, milho ou arroz.

7 Esse ritual consiste em encher cuias de calugi e fazer o xiwé, uma pequena frase (hãã hereinihè) que invoca os espíritos dos antepassados e também dos aruanãs para tomarem o calugi. Após os espíritos tomarem a parte espiritual da bebida, então os homens tomam a parte física dela.

8 “Os aruanãs são os inỹ roko ("os últimos humanos"), aqueles humanos subaquáticos que não passaram para o nível terrestre quando os outros subiram para conhecer a iluminação solar, sendo transformados então em aruanãs" (RODRIGUES, 2008, p. 273).
} 
encontrados pelos caçadores, por isso que eles recebem especialmente a comida $\left(\right.$ suru $\left.^{9}\right)$ pelos homens caçadores. O primeiro a comer é o espírito de homem branco (tori-kuni), seguido depois pelos caçadores. Assim era a realização das caçadas na cultura do povo Inỹ/Javaé.

Existem os espíritos bons (iwowi), que gostam de oferecer suas comidas, como as tartarugas, os porcos queixadas, patos selvagens e o mel silvestre. Quando o mel silvestre (bidi-tyhy) existe em algum local também ocupado por algum espírito de aruanã, quando o hàri pede, os espíritos fazem aumentar seu mel silvestre.

Antigamente o aumento de animais ou mel silvestre nos lugares dependia da comunicação dos hàri (xamã) com os espíritos de aruanãs. Quando tem muitas tartarugas nos lagos ou no rio Javaés, diz-se que é o hàri (xamã) quem tirou, ou seja, trouxe as tartarugas para o mundo aqui fora (ahana-òbira). Todos aqueles animais que os Iñ̃/Javaé consumiam eram trazidos pelo hàri, na relação dele com alguns espíritos de aruanãs. Todos os espíritos de aruanã são bons e eles sempre estão oferecendo suas comidas para o hàri. Mas tem os hàri ruins. Eles impedem a saída dos animais para os povos consumirem. Eles querem que os povos fiquem sem comer esses animais, como os porcos queixadas, os patos selvagens, as tartarugas e os peixes piabanhas. É dessa forma o papel do hàri ruim na cultura dos povos Inỹ/Javaé da Ilha do Bananal.

\section{Povos de Imõtxi}

Entre os povos antigos que moravam no centro da Ilha do Bananal, havia os da aldeia antiga Wari-Wari que ficava no interior da ilha a aproximadamente $14 \mathrm{~km}$ da margem do rio Javaés. E as outras aldeias ficavam na margem do Riozinho, como a aldeia antiga Imõtxi. Depois de epidemias que ocorreram no tempo do Serviço de Proteção aos Índios (SPI), na primeira metade do século XX, os sobreviventes se mudaram para mais longe de Imõtxi e criaram uma aldeia na margem do mesmo Riozinho chamada de Wajukabu (número 52 no mapa), ao norte da Ilha do Bananal, no lugar chamado Wabe. Mais distante ainda fizeram a aldeia Wabe-mahadu. Outras famílias foram no rio Jaburu e fizeram outra aldeia (Kuritiwi [número 15 no mapa - Figura 1]).

Suru é preparado com as vísceras (um tipo de buchada) de porcos queixada. 
Odair Giraldin e Ricardo Tewaxi Javaé

Espaço, Tempo e Narrativas: reflexões sobre a cultura Iñ̃/Javaé, Ilha do Bananal, Tocantins, Brasil

Figura l - Mapa das aldeias Inỹ/Javaé antigas

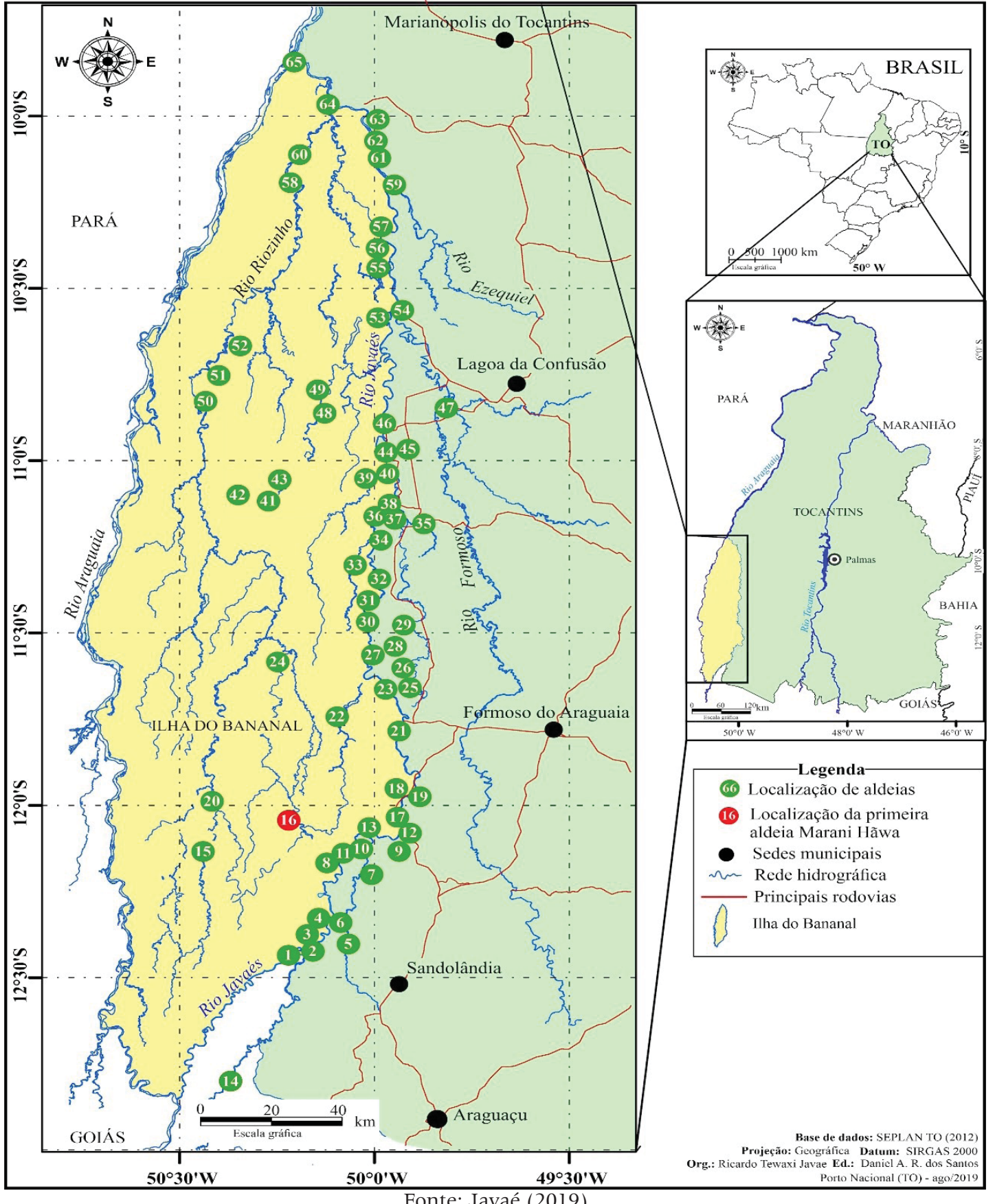


Espaço, Tempo e Narrativas: reflexões sobre a cultura Iñ̃/Javaé, Ilha do Bananal, Tocantins, Brasil

Quadro 1 - Nomes das aldeias representadas na Figura 1

\begin{tabular}{|c|c|c|c|}
\hline $\begin{array}{c}\text { Código no } \\
\text { mapa }\end{array}$ & Aldeias & $\begin{array}{c}\text { Código no } \\
\text { mapa }\end{array}$ & Aldeias \\
\hline 1 & Barreira Branca & 33 & Antiga Kuira Hawa \\
\hline 2 & Antiga aldeia Cachoeirinha & 34 & Kyrysa Hãwa \\
\hline 3 & Waritaxi & 35 & Horeni \\
\hline 4 & Barra do rio Verde & 36 & Làràtxi-ijo \\
\hline 5 & Itxala & 37 & $\begin{array}{c}\text { Hèdèdura-luku (barra do } \\
\text { Loroti) }\end{array}$ \\
\hline 6 & Ijanakatu Hawa & 38 & Hèdèdura-luku (lado da ilha) \\
\hline 7 & Ihõ-Buruna & 39 & Txuòdè \\
\hline 8 & Waxinabò & 40 & Dejueho-ijo \\
\hline 9 & Manatèrè Hãwa & 41 & Wararè-kòna \\
\hline 10 & Tabàlàna & 42 & Karalu Hawa \\
\hline 11 & Taimy & 43 & Syrahaky \\
\hline 12 & São João & 44 & Wyhy-raheto-di-ijarana \\
\hline 13 & Hitxala-ijo & 45 & Walairi \\
\hline 14 & Bòtòrèry Ijò & 46 & Waotyna \\
\hline 15 & Kuritiwi & 47 & Hakuti Hãwa \\
\hline 16 & Primeira aldeia Marani-hawa & 48 & Kywako-ro \\
\hline 17 & Atual aldeia Marani-hawa & 49 & Rara òky \\
\hline 18 & Atual aldeia Kanõanõ & 50 & Hãwarahedà \\
\hline 19 & Primeira aldeia Kanõanõ & 51 & Bòtòrèriòrè \\
\hline 20 & Juani & 52 & Wajukabu \\
\hline 21 & Txuiri & 53 & Inỹwèbohona \\
\hline 22 & Lòreky & 54 & Boto Velho \\
\hline 23 & Imotxi 2 & 55 & Hãrikò \\
\hline 24 & Imotxi & 56 & Narybykò \\
\hline 25 & Hãwariè & 57 & Manaburè \\
\hline 26 & Horeni & 58 & Narybykò \\
\hline 27 & Hãwahyrè & 59 & Irodu-iràna \\
\hline 28 & Susò & 60 & Nibònibò \\
\hline 29 & Kuira Hãwa & 61 & Bòròrè-wa \\
\hline 30 & Boa Esperança & 62 & Bòròrèwa \\
\hline 31 & Wari Wari & 63 & Txireheni \\
\hline 32 & Bela Vista & 64 & Wabe-ijo \\
\hline
\end{tabular}

Os povos indígenas da Ilha do Bananal se movimentavam pelos seus territórios principalmente na época de tartarugas desovarem nas praias. Pelos costumes dos antigos povos de Imõtxi, eles visitavam todos os anos seus parentes de Wari-Wari, que sempre recebiam seus visitantes com as lutas corporais. Quando era o tempo sem chuvas (maio a novembro), eles iam até as praias e acampavam. Chegavam até a levar os espíritos de aruanãs juntos, pois eles não os deixavam sozinhos nas aldeias. Era costume tradicional 
passar os tempos de seca também na margem do Riozinho. Ali, logo abaixo da aldeia Imõtxi, há um lugar chamado Ijyny-kòwò. Era feito pelos homens um tipo de canal (kòwò) perto de rio ou um lago para formar uma passagem de peixes, onde pescavam peixes e tartarugas com as flechas. Quando era chegada a estação chuvosa, voltavam para suas casas.

$\mathrm{Na}$ antiga aldeia Imõtxi foi onde se instalou o primeiro posto do Serviço de Proteção ao Índio (SPI). Os funcionários vieram de Santa Isabel do Morro (Hawalò), montados em cavalos e usando carros de boi, trazendo ferramentas para distribuir para os Inỹ/ Javaé do centro da Ilha do Bananal. Pessoas de outras aldeias vieram para receber as ferramentas, como as pessoas de Hèdèdura-Luku mahadu, as pessoas de Wari-Wari e da antiga Marani-Hawa. Os Iwayrè (Karajá) vieram como intérpretes para comunicar com os povos Inỹ/Javaé, porque esses não tinham conhecimentos de língua portuguesa. Mas não durou muito tempo o SPI nos povos Inỹ/Javaé, pois, com as novas epidemias, eles voltaram para aldeia Santa Isabel do Morro (Hawalò) no Araguaia.

O povo de Imõtxi tinha os rituais de espíritos de aruanã, os rituais de espíritos de outros índios "selvagens" (Ixyjukuni [ver Figura 2]), e também existia o iòlò. Mesmo com uma população pequena, realizavam seus rituais, como a iniciação dos meninos para passagem para fase adulta (Hetohoky = casa grande). Em um ritual desses, os espíritos de $i h \tilde{o}^{10}$ não conseguiram terminar as suas estradas no mesmo dia porque lá na região há muitas pedras. Por isso que o lugar é chamado de ihõ mana kòdòna (ihõ = espíritos que participam no final de ritual; mana = as pedras; kòdòna =, o lugar onde foram ajuntadas as pedras).

Dentro do hábito alimentar dos Inỹ/Javaé da Ilha do Bananal, em geral, a preferência está no consumo de peixes e carne de tartaruga, carne de porcos queixadas e patos selvagens. Esses são pratos especiais para os povos Iny. Muito raramente se come cutia, caititu, paca, macaco, quati, veado cervo, veado mateiro, veado catingueiro, anta, capivara, macaco guariba, camaleão, bem como os pássaros jacu, mutum, mergulhão.

Todas as caçadas dos animais especiais eram realizadas de forma coletiva, como as caçadas de porcos queixadas, esperas de patos selvagens, as pescarias de tartarugas e também coletas do mel silvestre.

${ }^{10}$ Ihõ é um dos espíritos worysy que participa no final do ritual de iniciação Hetohokỳ. 
Figura 2 - Kyrysa (esq.); Ixyjukuni (ambos ao centro); e kòrera (dir.)

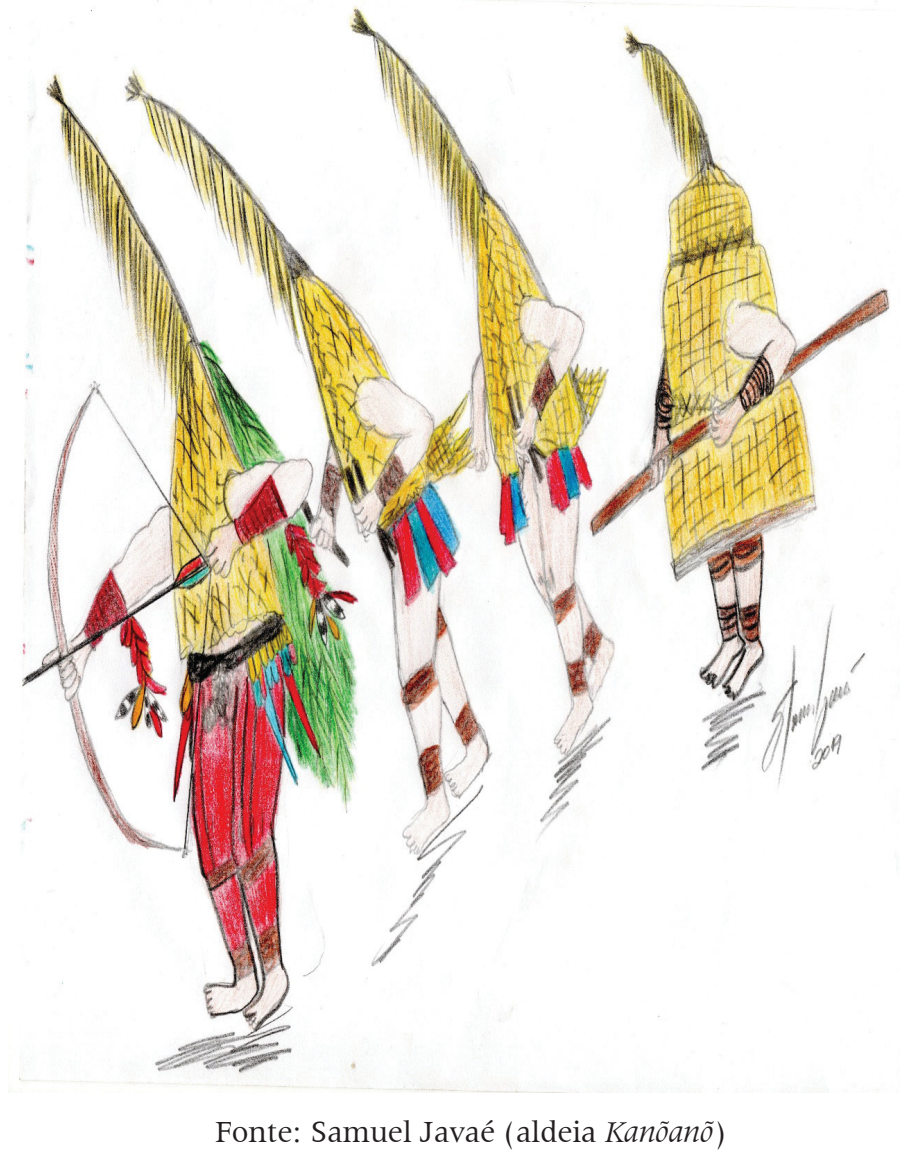

\section{Povos de Wari-Wari}

Os povos antigos de Wari-Wari habitualmente passavam o verão nas praias das margens do rio Javaés onde realizavam os rituais de espíritos de aruanãs como se fosse nas suas aldeias, bem como a realização de ritual Ixyju kuni (os espíritos de outros índios não Inỹ). Quando o rio Javaés começava a encher, os povos voltavam para sua aldeia de origem. Eles se movimentavam mais do que os outros povos Inỹ/Javaé da Ilha do Bananal. Desciam navegando o rio Javaés até o Txyreheni (atual Canguçu $)^{11}$, navegavam pelo Riozinho e circulavam também fora da Ilha do Bananal. Havia um povoado não indígena no lugar que existia um garimpo de cristal $^{12}$ (karinbu) onde os povos antigos pegavam roupas, algumas ferramentas, trocando com tartarugas ou couros de animais.

Eram reconhecidos como Ityhy (verdadeiro, forte, original), pois eles eram muito potentes. Esse reconhecimento se dava porque próximo das suas aldeias não existiam os pés de coco babaçu para extrair palhas para cobrir as suas casas. Ainda assim, eles faziam suas casas grandes e realizavam seus rituais de Hetohokỳ e carregavam as folhas

\footnotetext{
${ }^{11}$ Local onde existe um centro de pesquisa e ecoturismo mantido numa parceria entre a Universidade Federal do Tocantins e a OSCIP Instituto Ecológica. Consultar em: https://ww2.uft.edu.br/cangucu.

12 A região do planalto central, ao Leste da Ilha do Bananal, é rica em cristal de rocha (quartzo) e nos anos de 1940 teve início a exploração desse mineral.
} 
de babaçus para realização de seu ritual das margens do rio Javaés, a uma distância de aproximadamente $18 \mathrm{~km}$, sendo que ocasionalmente buscavam esse material em Kanõanõ.

Antigamente, cada povo vivia em seu território, nos lugares onde buscava sua sobrevivência como nas pescarias, nas suas caçadas e em seus acampamentos (syrana). Em cada região existia os recursos naturais, como as plantas medicinais com as quais realizavam as curas de enfermos. E também existiam os recursos naturais muito importantes na cultura do povo Inỹ/Javaé, como os taquaris que serviam para fazer flechas e o pati, para fazer os arcos. Esses recursos naturais serviam para fazer as armas dos homens, porém não existiam em todas as regiões. Os povos de Wari-Wari buscavam longe os taquaris e os pati e também a embira (tytè). Os taquaris só existem nas regiões de Imõtxi, enquanto os tytè só existiam na região de Kanõanõ.

Uma forma de acessar esses recursos era por meio de trocas pelos materiais existentes na região de Wari-Wari, como as penas de pássaros colhereiros, jaburu, gavião, arara vermelha e arara azul. Essas penas de pássaros são as que precisavam nas confecções de flechas e adornos. Existiam poucos pés de árvores chamadas tarumã para fazer os seus remos, os quais eram abundantes na região de Ikòrò-tòbò (atual aldeia São João [número 12 no mapa]).

O lago do Sohoky é um lugar em que historicamente aconteceram coisas fantásticas com os povos muitos antigos que ali viveram. Havia um bicho feroz (hanatxiwe) que tinha feição de gente. Como ele era dono da chuva, fez chover muito provocando uma grande enchente. Com isso, todos os seres do rio escaparam e passaram a atacar as pessoas. Piranhas gigantes e peixes bicudas gigantes passaram a correr atrás das pessoas e matá-las. As pessoas corriam para todos os lados, seguidas pelos gigantes. Por isso que o formato do Sohohy é irregular daquela maneira, pois marca os lugares em que as pessoas corriam e os peixes as atacavam. Só tinha um homem que havia escapado, chamado Buritxiwana. Ele era atleta, pois fazia treinamentos constantes e por isso que correu muito e conseguiu subir no pé de jenipapo ${ }^{13}$. A bicuda gigante não conseguiu alcançá-lo. Com isso, após exterminar quase todo mundo, Hanatxiwe afundou-se no lago e foi embora e até hoje continua morando no nível subaquático. Então por isso que o lago ficou daquele formato, sendo muito largo, semelhante ao tamanho do rio Araguaia.

Existem duas mulheres sem os olhos que moram no fundo das águas do lago Sohoky. Elas também são seres ferozes que são chamadas de Wanymy-sekeseke e Bwanymy. Elas são donas de frutos chamado de jenipapo, bem doce. Quando Tynyxiwè ${ }^{14}$ andava pelo mundo, encontrou aquelas duas tirando os frutos. Tynyxiwè pensou: nossa, quem serão elas? Chegou perto delas e observou que não tinham os olhos. Então Tynyxiwè pensou: nossa, vou comer os frutos que elas estão colhendo. A Wanymy-sekeseke, jogou o fruto. Tynyxiwè pegou antes de cair na mão de Bwanymy. Ela falou para sua irmã: cadê o fruto? Joguei aí, disse Wanymy. Aqui não está, falou Bwanymy. Tynyxiwè comeu o fruto de jenipapo e ele gostou: nossa, que fruto doce, muito gostoso. Tynyxiwè pensou: vou comer de novo. Foi de novo pegar a fruta. Mas dessa vez, Bwanymy tinha pegado a fruta junto com a mão de Tynyxiwè. Ela chamou a outra que estava lá em cima: peguei! Lá vai outra, segura! Então Tynyxiwè puxou e arrancou um dos dedos da sua mão para escapar dela e correu. Elas correram

\footnotetext{
13 A única árvore que consegue proteger as pessoas e impedir a ação desses seres ferozes é o pé de jenipapo.

14 Tynyxiwè é um herói transformador que proporcionou, entre outros, o clareamento deste mundo com a fixação do Sol no firmamento, as mudanças de alguns seres humanos e animais. Ver Rodrigues (2008).
} 
atrás de Tynyxiwè. Ele correu até se cansar. Então ele pediu socorro para a anta substituilo na corrida, pois estava muito cansado. É por causa disso que temos só os cincos dedos de cada mão. Antes eram seis dedos de cada uma das mãos.

Com os conhecimentos de hàri, os xamãs conseguem andar por todo o mundo cósmico em todos lugares: nos níveis celestes, no nível subaquático e aqui no mundo a fora (ahana-òbira). Então eles chegam na casa das duas mulheres sem olhos (wanymysekeseke) e lá existem os frutos de jenipapo. Os xamãs comem os frutos de jenipapo muito doce. Antes elas moraram no mundo aqui fora e depois que foram morar no nível subaquático do lago de Sohoky. O hanatxiwe morava no fundo de um buraco da terra. Depois que acabou com os povos, foi morar no fundo das águas no lago. Ele também é o dono de chuvas. Quando está faltando as chuvas, os hári pedem a ele a chuva. Então chove muito para encher os rios e os lagos e a ilha toda fica inundada, não só na região de Sohoky, mas toda a região da Ilha do Bananal.

Assim, as histórias da região de Sohoky são narradas pelos nossos ancestrais. Muito antigamente o Sohoky era do tipo de um rio estreito e a antiga aldeia era chamada de Kujejeni-mahadu. Depois que foi feito o lago bem maior, pelos ferozes que perseguiam as pessoas, foi chamado de Sohoky ( $s o o=$ no meio, ou seja, fundura; $k y=$ algo maior ou de muito respeito pelas pessoas). A palavra soo é usada para a parte de dentro de uma canoa e também é usada para os lagos ou rios, com referência a profundidade. O Sohoky é o maior lago na Ilha do Bananal (que fica na região de atual aldeia Txuiri, à distância de $18 \mathrm{~km}$ da margem do rio Javaés).

\section{Os Povos Antigos do Sul da Ilha}

A parte sul da Ilha do Bananal, na margem do rio Javaés, ficou pouco habitada por muito tempo pelo desaparecimento dos primeiros povos, que pode ter sido ou pela atuação dos Bandeirantes, ou por fuga, como aconteceu com um dos povos, que se chamava Wala, que voltou para o nível subaquático do lago Wala Ahu (atualmente Lago da Piranha), na antiga área da Fundação Bradesco ${ }^{15}$, mas que atualmente é parte dos assentamentos rurais existentes na região. Segundo as narrativas, eles ficaram com medo dos Tori uhu (Bandeirantes) e se transformaram novamente em espíritos (aruanã = irasò) e voltaram para o mundo de origem. Esse medo é justificado, pois as narrativas descrevem como extremamente violentas as ações praticadas por esses Tori-uhu, seja matando ou capturando as pessoas. Um dos povos atacados por esses estrangeiros foi o povo de Tòròhòni, que foi levado pelos Tori-uhu de seu lugar para Goiás e nunca mais voltaram para o seu lugar de origem ${ }^{16}$. Devido a essa característica de belicosidade e de

\footnotetext{
15 A Fundação Bradesco adquiriu uma extensa área rural do município de Formoso do Araguaia. Segundo Rodrigues (2013, p. 93), era a "Fazenda Canuanã, que havia sido comprada no início dos anos 60 por três irmãos da rica família Pazzanese, de São Paulo. Entre os irmãos, destacava-se o médico paulista Dante Pazzanese (1900-1975), cardiologista renomado, que fundou a Sociedade Brasileira de Cardiologia em 1954 e o Instituto de Cardiologia do Estado de São Paulo, mais tarde nomeado como Instituto Dante Pazzanese de Cardiologia - Fundação Adib Jatene". O nome oficial da escola é Colégio Dr. Dante Pazzanese, em homenagem ao cardiologista e mantido integralmente pela Fundação Bradesco. Essa foi a primeira escola-fazenda da Fundação Bradesco e foi fundada em 5/07/1973. Consultar em: https:// fundacao.bradesco/Escolas? ID =9.

16 Possivelmente foram levados, no século XVIII, pelo sertanista Antônio Pires de Campos para o aldeamento de São José de Mossâmedes, em Goiás, e depois para o aldeamento de Santana do Rio das Velhas, no Triângulo Mineiro. Ver sobre esse processo em Mori (2015).
} 
grande poder letal contra os Inỹ, um desses tori uhu foi morto nesses confrontos e seu espírito foi apropriado tornando-se um grande espírito auxiliar dos xamãs nos processos de cura e de defesa do povo Inỹ/Javaé (JAVAÉ, 2019, p. 117).

Também existiu uma aldeia fora da Ilha do Bananal, chamava de Kyrysa-Hawa (número 34 no mapa), mas que era ocupada por pouco tempo. Já a aldeia Hèdèdura-luku (número 38 no mapa) ficava dentro da ilha e depois seus moradores fizeram uma outra aldeia (número 37 no mapa). A aldeia Txuòdè (número 39 no mapa) sempre ficava na ilha enquanto a aldeia Wyhy-Raheto-Di-Ijarana (número 44 no mapa) ficava sempre fora da ilha e os povos que moravam nela passavam os meses de verão nas praias na margem do rio Javaés, dentro da ilha, conforme era o costume dos povos antigos.

Os povos de Làràtxi (número 36 no mapa) passavam o verão nas praias da margem do rio Javaés do lado da Ilha do Bananal. Esses antigos povos realizavam seus rituais de espíritos de aruanãs e ritual de Ixyjukuni. O ritual não durava nem um dia inteiro, pois começava a tardezinha e terminava por volta das nove horas da manhã do dia seguinte e era realizado no meio de farturas das roças e nesses momentos aconteciam bòròtyrè ${ }^{17}$, um ritual em que as mulheres comiam as comidas de Ixyjukuni, para pedir em troca algumas coisas da família dona de espírito, como alimentos ou alguns objetos. E a família dona de espíritos dava o que as mulheres pediam.

Para os antigos povos de Wyhy Raheto-Di-Ijarana, o lugar de pescar era no lago de Walairi. Walairi era um povo que surgiu na região de Wyhy-Raheto-Di-Ijarana, fora da Ilha do Bananal. Os povos Inỹ/Javaé que moraram nessa antiga aldeia estiveram em conflitos com os Iwayrè-Karajá. Eram poucas famílias e os Karajá mataram quase todos os moradores de lá. Os sobreviventes foram morar na antiga aldeia Karalu-Hawa (Pataca [número 42 no mapa]) e Bedeky, no norte da Ilha do Bananal. Depois de muito tempo fizeram a aldeia Ruku-wèbòhòna, ou seja, Inỹ wèbòhòna (conhecida também como Boto Velho [número 53 no mapa]), o lugar onde estourou a barriga dos ancestrais $\operatorname{In} \tilde{y}^{18}$, na região conhecida também como Tori-Bero-ijò (a foz do Rio Formoso). A primeira aldeia foi criada fora da Ilha do Bananal, na área atual Barreira da Cruz, uma fazenda existente na margem direita do rio Javaés, na confluência com o Formoso. Quando os não indígenas chegaram na região, mandaram os povos Inỹ/Javaé serem retirados da sua própria aldeia e, por isso, foram morar na Ilha do Bananal. Assim, os primeiros moradores contam que os cemitérios e os lugares de casa dos homens foram todos abandonados.

\footnotetext{
${ }_{17}$ Bòròtyrè são uma classe especial de parentes que estão presentes em importantes momentos do ciclo de vida de uma pessoa. Eles imitam os atos que ocorrem com seus parceiros, recebendo em troca algum tipo de recompensa. "Essa categoria de parentes surgiu miticamente quando Tanỹxiwè cortou o cabelo do iòlò Urubu Rei, de quem roubou o cocar/ sol. Conforme diz o mito, os urubus que eram tios do iòlò, incluindo homens e mulheres, imitaram o gesto, cortando os seus cabelos" (RODRIGUES, 2008, p. 615).

18 Esse episódio é assim narrado. Um jovem jyrè (recém-iniciado) foi pressionado por sua mãe a revelar os segredos dos homens existentes na casa de Aruanã. O menino revelou um segredo. Porém um hàri (xamã) ouviu e contou aos homens quando voltaram de uma pescaria. Ato contínuo, decidiu-se que todos deveriam morrer para acabar com o mau provocado pela quebra do segredo. Os guerreiros fizeram três buracos (um para homens, outro para mulheres e outro para crianças). Em seguida, acenderam fogueiras nesses buracos e passaram a matar as pessoas e lançar seus corpos nas fogueiras. As barrigas das pessoas estouravam com o calor do fogo. No final, os dois últimos guerreiros se flecharam mutuamente e caíram também nas fogueiras. Somente dois meninos se salvaram, pois foram escondidos por sua mãe em um buraco dentro de casa, cobertos por uma panela de barro.
} 


\section{Os Antigos Povos de Pataca}

Eles habitaram na região norte da Ilha do Bananal, sendo conhecidos como Bedekymahadu, sendo que Bede significa espaço ou mundo, $k y$ significa dentro ou meio e mahadu é um povo, ou grupo. Teve epidemias na Pataca e os que sobreviveram vieram para morar na margem do Javaés, na região de Boto Velho. Eram poucas famílias, mas que deixaram seus lugares de origens e nunca mais voltaram aos seus territórios, onde eles viviam nos lugares diferentes nas margens dos lagos e se deslocavam de um lago para outro a pé, por que não existe nenhum rio na região.

Os rituais praticados pelos Bedeky eram os mesmos dos Javaés das margens de rio Javaés, como o ritual dos espíritos de aruanãs (irasò) e também existia ritual de iniciação de Hetohokỳ. E faziam também o ritual de espíritos de outros indígenas (ixyjukuni, sendo ixyju o índio não inỹ e kuni significa espírito, ou alma das pessoas). As demais manifestações culturais eram as mesmas da região sul da Ilha do Bananal.

Só que o costume tradicional de acampamentos era muito diferente daquele dos povos da margem do rio Javaés. Eles andavam a pé de um lugar para outros nos lagos. Eles se deslocavam de canoa só quando era tempos de enchentes, quando então iam para lugares distantes onde visitavam seus parentes, como na aldeia Marani-Hawa, aldeia Imôtxi e na aldeia Wari-Wari, pelo varjão alagado (bedero).

A região mais antiga que eles habitavam era na aldeia Wararè-kòna (número 41 no mapa), uma aldeia que significa o lugar onde as ninhadas de colhereiro existiram. Wararè é o colhereiro e kòna são os ninhais nas árvores nas margens de um lago. Os povos muitos antigos habitavam nas margens do atual Lago do Mamão. Mas nunca mais voltaram a morar naquele lugar. Eles habitavam mais na margem do lago Pataca (Karalu-Háwa [número 42 no mapa]). Quando era o tempo de enchentes, alagava tanto o Wararè-Kòna (atual Lago do Mamão) quanto o Karalu-Hawa (atual Lago do Pataca). Como nessas duas regiões não existem os lugares altos, eles passavam muitas dificuldades para fazer suas roças. Faltavam muitas coisas para o plantio da roça. Com o passar dos tempos, encontraram um lugar elevado e era ali que eles faziam suas roças e plantavam muitas bananas, abacaxi, milho, mandioca, batata doce, cará, etc. Esse lugar chama-se Syrahaky (número 43 no mapa). O nome Syra significa quando os peixes iuiu (Syra) ficam presos no laguinho nos varjões (haky). Esse lugar é alto o suficiente para não ser alagado no tempo das enchentes e tem muitos matos e espaços bem amplos, reconhecidos como coração da Ilha do Bananal.

Os Bedeky também fizeram outra aldeia, Kywako-ro (número 48 no mapa), sendo que o nome kywa significa jatobá, kò significa pé e ro é um poção de um lago. Portanto, o nome refere-se a um poção de pés de jatobá. Depois mudaram novamente para outro lugar chamado de Rara-òky (número 49 no mapa), onde rara é urubu e òky é abundância. Só que esse nome não se refere ao pássaro urubu, mas sim porque no lugar existem muitas plantas nativas chamada de rara-kò. Essa aldeia, que foi a última dos Bedeky, já fica um pouco mais perto do rio Javaés. De lá que eles vieram pelo rio Kaxiwewo (Murere), que desagua no rio Javaés. Então os Bedeky definitivamente deixaram os seus lugares de origens dentro do espaço do interior da ilha, vindo a morar nas margens do rio Javaés (Bero-biawa). 
Foi nessa região da Pataca que no começo do mundo aconteceu um episódio entre dois irmãos, Ahulawari e Ijelawari. Ijelawari namorou com a sua cunhada, esposa de Ahulawari. Ele falou para seu irmão Ijelawari subir no pé de árvore para pegar os filhotes de jaburu tuiuiú. Quando Ijelawari subiu e, como castigo, ele fez o pé de árvore se elevar ficando muito alta impedindo que Ijelawari descesse de volta. Ele ficou lá em cima muito tempo. A mãe de tuiuiú quase que matou ele e o pai de tuiuiú o defendeu. Assim Ijelawari ficou no ninho e quando os filhotes de tuiuiú cresceram e voaram, o pai de tuiuiú convidou todos os pássaros a descerem Ijelawari de volta. Muitos pássaros se reuniram e levaram ele de volta para sua família. Assim é a história contada pelos narradores Inỹ/Javaé.

O lago do Pataca é muito sujo. Mesmo assim os povos antigos consumiam as águas do lago. E eles pescavam no lago sujo e matavam os peixes flechando sem ver. Se orientavam só pelo sinal no meio das águas para atirar as flechas. O hábito alimentar dos povos eram os peixes mais gordos como o pirarucu (budòlèkè), pirarara (turè), surubim (harètu), tucunaré (bènõra). No lago existiu (e ainda existem) muitos desses peixes. Também existem muitos porcos queixadas, muitos patos selvagens e o mel silvestre é abundante na região. A população sempre foi pouca, mas mesmo assim eles realizavam seus rituais, como o dos espíritos de aruanã.

Os Bedeky só faziam o ritual de hèrèrawo, também chamado de hijè-rurè, furar o lábio de criança menino (hijèti significa lábio e rurè é furo). A duração desse ritual era de poucos dias. Esse ritual é da mesma forma que Hetohokỳ e envolve as pessoas como os parentes mais próximos, os hàri e o chefe de ritual (ixy tyby) ${ }^{19}$. Eles faziam também ritual de aruanã e os lateni $i^{20}$. A reclusão começava dentro de casa de seus pais. Os lateni dançavam ao redor das casas dos meninos um dia e uma noite toda. Na manhã seguinte, os meninos eram levados pelos seus tios maternos e tios paternos e os lateni iam acompanhando até no pátio dos homens e lá os tios e os latenis seguravam os meninos para furar os lábios com o osso de macaco guariba. Alguns meninos continuavam a reclusão na casa grande (Hetohokỳ) e viravam Jyrè (ariranha). Outros iam até o pátio dos homens só para furar o lábio e de lá voltavam para sua casa. Os tios e os latenis levavam de volta nas casas de seus pais onde continuavam como uma criança menino. Antigamente os meninos tinham que passar no ritual de furar o lábio. O tio que furava o lábio de seus sobrinhos e algumas crianças continuavam no ritual e passavam trinta dias de reclusão, recebendo os conselhos na casa grande dos worosy, espíritos que moram no mundo subaquático do Riozinho (worosy-bero). Hoje em dia não existe este ritual de hijè-rurè, sendo que a última realização se deu nos anos 1960. Todos os antigos povos da Ilha do Bananal, Inỹ/Javaé e também o Inỹ/Karajá e os povos Ixy Biawa, faziam este ritual de furar o lábio. Hoje em dia as novas gerações não conhecem esse ritual.

Então, cada povo Inỹ/Javaé nas suas regiões realizava seus rituais de formas diferentes, como a iniciação de meninos para fase adulta. Nas aldeias com população menor, realizavam o ritual hèrèrawo, ritual de duração mais curta. As aldeias maiores, como antigo Wari-Wari, não existia o ritual de hèrèrawo, mas sim o Hetohokỳ (casa grande).

\footnotetext{
19 O nome ixy significa aldeia, mas também é porco queixada e tyby significa pai; então o nome se refere ao pai das pessoas daquela aldeia.

20 Lateni são seres humanos mascarados que atuam com "guardas" da casa dos homens e protegem os jovens jyrè durante o ritual de iniciação de Hetohokỳ. As máscaras são semelhantes àquelas dos aruanãs, porém os Inỹ/Javaé não os consideram como sendo aruanã.
} 
Também não existia o ritual de Hetohokỳ-wèkèrè (wèkèrè significa metade), ou seja, apenas a metade do ritual. Esse ritual de iniciação de criança para a fase adulta tem pouca duração sem ter lateni. O menino não ficava de reclusão. Os tios enfeitavam o seu sobrinho e levavam na casa dos homens quando tem a brincadeira maior de aruanã como kobiku (peixe assado), ou iwodudu (o peixe enrolado de massa de mandioca, tipo pastel). Os meninos recebiam orientação sobre os segredos da casa dos homens e no final do dia voltavam para a casa materna. Só recebia o conselho de worosy dentro de casa dos homens e terminava. Já viravam Jyrè (ariranha). O povo Marani-Hawa, também só realizava o ritual de Hetohokỳ, porque lá existia uma grande população e havia também a realização de ritual de Iwèruhuky, prestígio dos iòlòs. O nome iwèru é uma bebida típica do povo Inỹ/Javaé que se faz da fermentação de milho e de mandioca, huky é seio, ou algo maior, mas também usado para as pessoas com muito respeito. O ritual de Iwèruhuky, tem duração de mais tempo (cerca de trinta dias) e quando era realizado não se faziam outros rituais. No meio desse ritual, mesmo a festa de espíritos de aruanãs parava. Toda tarde (entre quatro e seis horas da tarde) os homens e os meninos participavam e dançavam em forma de círculos no pátio dos homens. Paravam. A noite continuavam juntos com as mulheres nas cantorias na porta da casa do iòlò, o conselheiro formal da comunidade.

O ritual Iwèruhuky começava após de ritual de Hetohokỳ, aproximadamente no mês de abril e terminava no mês de maio. Esse ritual não se realiza mais atualmente. Então esse ritual envolve todas as personagens das comunidades, como o hàri (xamã), ixy-tyby (chefe do ritual). Envolve também os iòlòs que são conselheiros formais da comunidade e também as mulheres (hawyky-mahadu), os meninos (uladu weryry) e também envolvem as competições de kòhurò. O nome kòhurò é um tipo de flecha sem ponta que era arremessada com um propulsor. As pessoas que participam são aquelas preparadas, ou seja, aquelas específicas para competir com seus adversários. Essa competição envolve pessoas relacionadas por questão matrimonial. Um homem pede a sua irmã para que o marido dela faça o kòhurò. Esse cunhado não se nega porque é um pagamento do preço da noiva. E também envolviam os espíritos dos seres humanos (tyky tyby) e os participantes usavam de palavras maliciosas de conotação sexual entre homens e mulheres. Não existia o ciúme e só paravam de falar as palavras maliciosas quando terminavam os rituais.

\section{Làrãtxi}

A antiga aldeia Làràtxi (número 37 no mapa) ficava fora da Ilha do Bananal, onde atualmente é o assentamento rural de Capão do Coco, com assentados sem-terra. Conforme costume tradicional, os moradores de Làratxi passavam os meses de verão nas praias nas margens do rio Javaés. Os outros povos chamavam eles de Làràtxi-mahadu, ou de Hèdèdura-luku-mahadu. Na região existiram três aldeias e um lugar de morada de uma família: aldeia Horeni, atual assentamento de Capão do Coco; aldeia Hawa-riè e aldeia Hèdèdura-luku (número 38 no mapa). Mas também existiu um lugar só de uma família (Kuriawa-Haky Hawa). Apenas a aldeia Hèdèdura-luku ficava na margem direita do rio Javaés, fora da Ilha do Bananal. As duas outras e a morada da família existiram nas margens de rio Làràtxi, fora da ilha. 
Pelo costume tradicional do povo de Làràtxi, no ritual de iniciação de menino para a fase adulta, levavam eles para a casa dos homens sem cortar o cabelo e sem pintar de tinta de jenipapo para virar jyrè (ariranha). Eles chamavam de saura o menino que ficava na casa de aruanã na condição de worosy-wetxu. O nome worosy significa um espírito que fica sempre na casa dos homens, que são os espíritos de Tabuhana e Ijòwyra que se referem àqueles que acabaram com as pessoas na antiga aldeia Iny wèbòhòna (Boto Velho), quando fizeram os buracos e mataram todos. Wetxu é um tipo de servente, mandado pelos homens na função de buscar algumas coisas para a casa dos homens, como buscar água e cuidar da casa de aruanã. Todos os meninos iniciandos, como Jyré, ficam na condição de worosy-wetxu. Nessa mesma condição, ficam as mulheres que estão fazendo bòròtyre (acompanhante) com o menino.

Como cada povo Inỹ/Javaé de suas regiões tem seus costumes tradicionais diferenciados, específicos, na antiga aldeia Wari-Wari não existia esse ritual de saura. O espírito de Ixyjukuni kòrèra (jacaré-tinga - ver Figura 2) não existia na cultura dos antigos povos de Wari-Wari. Isso começou na antiga aldeia Tabàlàna (número 10 no mapa - figura 1), na região de Cachoerinha (Hèryrihikỹ [número 2 no mapa]) e ficava ao lado da região de Água Fria (Hitxala-wo [número 13 no mapa]), atual Fazenda Agua Fria fora da Ilha do Bananal. Na formação da aldeia Tabàlàna algumas famílias de Marani-Hawa se dividiram e vieram nas margens do rio Javaés e escolheram este lugar para morar e também vieram algumas famílias de Wari-Wari. Nesta aldeia Wari-Wari existiam os espíritos Ixyjukuni de outros indígenas, como o espírito de Kayapó (karalahu), espírito de Tapirapé (wou), espíritos de Apinaje (wabinõlè), espíritos de Walairi, espírito de Xavante (kyrysa-tyhy), além de espírito de Ava-Canoeiro (kyrysa) e espírito de não indígena [branco] (Tori). Então esses espíritos, quando havia fartura das roças nas comunidades, vinham para comer a melancia, o milho verde, a banana, a mandioca, a cana. Também vinham comer as carnes de tartarugas quando os homens pegavam muitos desses quelônios. As crianças recebiam esses espíritos dos seus tios, como será explicado a seguir.

\section{Relação entre Aldeias e com Outros Povos}

Antigamente havia muitos confrontos entre os povos indígenas. Tinham episódios de mortes, e os tios tiravam os espíritos de outros indígenas mortos e davam para seus sobrinhos, os quais ficavam para sempre nas famílias, transmitidos de geração a geração. As crianças recebiam esses espíritos (ixyjukuni) de seus tios como se fosse um presente, como um animal de estimação. Os ixyjukuni moram dentro de cupinzeiros e não protegem o seu "dono". Quem tem ação de proteção para as pessoas são os espíritos de aruanã, que estão presentes em momentos rituais e auxiliam no processo de crescimento das crianças, por meio de abraços e as suspendendo para fazê-las crescer rapidamente.

Assim acontecia na cultura dos povos Inỹ/Javaé. Atualmente, os tios estão dando de presente para seus sobrinhos muitos espíritos de jacaré tinga (kòrèra), espírito de jacaré açu (kòbòròrò) e o espírito de Ava-Canoeiro (kyrysa). Esses espíritos atuais são de pessoas não Javaé que morreram e podem ser tomados e dados de presente para uma criança. 
Cada espírito tem suas pinturas diferentes, específicas. Por exemplo: o espírito de Tapirapé (wou) é todo enfeitado com os enfeites e adornos nas pernas, nos braços e com as penugens nas coxas e nos braços; os espíritos de Kayapó (karalahu) só amarram as embiras nas pernas e nos braços e pintam de riscos pretos nas coxas e no meio dos riscos passam a tinta vermelha do urucum; o espírito de Apinaje (wabinõlè) também amarra as embiras nas pernas e nos braços e se pinta de urucum e carrega os filhotes de cachorro além de arco e flechas e borduna nas mãos, emitindo um grito específico; o espírito de walairi tem os enfeites nas pernas e nos braços e adornos todos brancos; o espírito de Ava-Canoeiro (kyrysa) anda com as flechas nas mãos, pintado de urucum e com as miçangas nos braços; o espírito de Xavante (kyrysa-tyhy) também anda com as flechas nas mão; finalmente, o espírito de não índio [branco] (Tori), anda com a calça velha rasgada e com espingarda nas mãos.

Essa materialização dos espíritos se dá com a confecção de máscaras (como as da imagem da Figura 2). Esses espíritos se apresentam no período quando existem roças maduras, sobretudo quando há milho verde ou melancia em abundância. Então, o tio que ofereceu o espírito ao sobrinho conversa na casa dos homens e decidem trazer os ixyjukuni para dançarem e animar a aldeia. Em troca, os espíritos recebem os alimentos que são levados e compartilhados na casa dos homens, que é o espaço masculino por excelência nas aldeias iny.

Antigamente existiam muitos confrontos no meio dos povos indígenas. Por isso que aconteciam esses presentes com os espíritos. Quando o tio ou o algum parente vencia nas guerras, faziam os espíritos, ou seja, transformavam o morto em espíritos e davam para seus parentes como se fosse um troféu do vencedor de guerra. Ao morrer, a parte material perece, mas a espiritual permanece. Por isso, é possível que o espírito possa ser dado de presente. Assim, esse espírito ixyjukuni tem mais um papel de demonstração do prestígio atribuído a determinadas famílias, por ter uma posição de destaque social advindo seja pelas roças que mantém, seja pela posição social da família, pois entre os Inỹ/Javaé há famílias com status diferenciados, como famílias "nobres" e famílias "Comuns" (RODRIGUES, 2008, p. 117-118).

Também existia (e ainda existe), o espírito de um Iwayrè (Karajá) de nome Saurè que se fazia passar por kyrysa, que os Javaé mataram na região de Bananal Velho (MaraniHawa). Aconteceu há muitos anos atrás, por que os Iwayrè (Karajá), se passavam de kyrysa (Ava-Canoeiro) ou de Xavante (kyrysa-tyhy), para atacar os outros povos. Assim foi narrado pelos mais velhos. Os Karajá de Santa Isabel vinham para confrontar com os povos Inỹ/Javaé. Eles iam várias vezes nas regiões de Marani-Hawa e o povo Inỹ/Javaé percebia que os kyrysa falavam quase que a língua materna Inỹ (inỹ rybè). E até hoje existem esses espíritos nas famílias que passam de geração a geração.

As famílias que recebem mais os espíritos dos outros indígenas são as que têm roças fartas e também os enfeites e adornos necessários para confeccionar as máscaras. Assim, filho de homem trabalhador (habu tyhy) junto com sua família (syrodèri), vai receber mais os espíritos. E, por isso, referem-se a essas crianças que recebem os espíritos como Ixyjukuni de uladu-tymyra, sendo que uladu significa criança e tymyra significa novo ou nova. A criança assim referida terá alto prestígio social, pois que demonstrará que está 
numa família de destaque, provavelmente uma família que consegue traçar linha de genealogia de nobreza.

Nos elos narrativos performados pelos anciãos, o nome do rio Formoso (Tori bero, rio dos não índio) é tratado como Tori-uhu bero. Assim os narradores usam duas formas: usam tanto Tari-bero (em que Tari significa um nome próprio feminino). Nesse elo, o nome refere-se ao rio da Tari. Outros narradores usam o nome Tori-uhu bero, no qual Tori-uhu significa os estrangeiros. Nesse caso, o nome refere-se a rio de estrangeiros que podem ser os Bandeirantes. Os povos antigos narravam que esses estrangeiros que os Iny não conheciam, matavam os indígenas Inỹ/Javaé. Como argumentamos anteriormente, devido a essa característica de força e capacidade bélica, o espírito de Tori-uhu tornou-se grande auxiliar dos xamãs para atos de proteção e cura.

Após as perambulações por todas essas antigas aldeias fora da Ilha do Bananal, os Inỹ fizeram a primeira aldeia Kanõanõ fora da ilha no ano de 1946, onde é a escola da Fundação Bradesco atualmente. A família do capitão Kuòruwa veio de aldeia Wari-Wari, por motivo de conflitos internos. O capitão Kuòruwa Javaé era hàri (xamã) e junto com seus irmãos Ijahina Javaé e seu irmão mais velho Ixyjuwèdu, que também era o chefe de ritual (Ixy-tyby), deixaram sua aldeia de origem Wari-Wari.

Depois de três anos os tori (não indígenas) chegaram na região, marcando o início da chegada dos tori na Ilha do Bananal. Chegaram a cavalo e com tropas de animais. Na primeira vez chegaram três pessoas que passaram três dias e depois foram embora. Passaram-se aproximadamente duas semanas, vieram muitas pessoas para procurar os lugares bem altos na Ilha do Bananal para morar. Um fazendeiro morou na aldeia dizendose amigo e vizinho dos índios. Depois esse fazendeiro vendeu a terra dos antepassados Javaé. Os moradores Inỹ foram reivindicar os seus direitos junto ao Serviço de Proteção ao Índio (SPI), na aldeia Barreira Branca (Tahakala [número 1 no mapa]). O servidor do SPI falou para os moradores de Kanõanõ para se retirarem de seus próprios lugares e mudarem-se para a margem esquerda do rio Javaés, dentro da Ilha do Bananal. Então os primeiros moradores foram retirados de suas casas, abandonaram sua aldeia, seus cemitérios e lugar de casa dos homens. Eles tinham ali os rituais de espíritos de aruanãs e também a realização de ritual de Hetohokỳ.

Assim, após a chegada dos tori na região, acabou o acesso a todos os lagos que existem nas regiões, que foram proibidos para os indígenas. E os cerrados, que eram os lugares onde os Inỹ/Javaé buscavam os frutos (como os muricis grandes, oiti, mangabas), foram desmatados pelos não índios. Mesmo assim, os lagos foram frequentados nas décadas de 70 a 80 pois os homens ainda pescavam furtivamente nos lagos $\mathrm{Ahu}$-huky (Lago Grande ou o Lago da Piranha) e lago da Mata Azul (bero-riòrè). Existe também um lugar chamado de hatykiyho (hatykiy significa uma fruta nativa e ho é abundância). Era um lugar de matas fechadas frequentado pelos homens que pescavam de arco e flecha no mês de março ou em abril, quando era época que cardumes de peixes que passavam por meio das águas que começavam a baixar nas enchentes. Na história dos Inỹ, esse lago se chama de Wala-ahu, em que o nome Wala é um povo que surgiu na região de Kanõanõ, no início do mundo. Com os conflitos após a chegada dos primeiros tori (os Bandeirantes), o povo Wala transformou-se em espírito novamente e voltou para o nível subaquático. 
Com o passar do tempo chegamos na situação atual em que há proibição de caçar e pescar e de coletar frutos nas regiões, bem como de retirar as plantas medicinais para curar os enfermos Inỹ/Javaé. A região era riquíssima de recursos naturais para confeccionar arcos e flechas e também de plantas que serviam para fazer esteiras e as plantas medicinais. Isso tudo não se encontra mais, devido ao desmatamento feito na região onde está o atual assentamento de Mata Azul.

Existiam também os indígenas Ava-Canoeiro na região de Mata Azul, porque a mata era grande e fechada ${ }^{21}$. Por isso que eles se escondiam na região. Os não indígenas os atacavam e os matavam. Com os Inỹ/Javaé não se encontravam e não tiveram confrontos. Os povos Inỹ/Javaé só tinham visto os sinais da presença deles nas margens de lagos.

No rio Formoso (Tori-bero), quando era o tempo de enchente, os moradores antigos iam de canoa para pegar as tartarugas. Mas quando eram os meses de verão (sem chuva), eles iam a pé e carregavam as tartarugas nos cestos masculinos chamados de bèhyra. Hoje em dia, há necessidade de pedir uma autorização para o IBAMA e não podem ser capturadas muitas tartarugas, pois quando é autorizado, já se estipula a quantia que pode capturar. Os antepassados frequentavam sem preocupação e usufruíram dos lagos ou espaços nos diversos lugares, pois era o hàri, que nos mundos cósmicos tinha comunicação e ligação com os espíritos de aruanãs, que atuava para aumentar mais as tartarugas nos lugares de um rio ou de um lago.

Então só tinham essas comunicações dos hàri com os espíritos de aruanãs, que era o dono das tartarugas nos lugares. Porque no mundo os espaços são sempre ocupados pelos espíritos de aruanã, como no mundo subaquático (bèra hatxi kanawèbòròribi) e nos níveis celestes (biu wètyky). Nessa cosmologia, as coisas são comandadas pelos espíritos de aruanãs, seja nos rios, nos lagos ou nas matas, assim sendo desde o mundo dos nossos antepassados. Os nossos ancestrais tinham outras formas de realizar as suas tarefas e as atividades culturais nos espaços, como nas pescarias de tartarugas e as caçadas de porcos queixadas nas matas. Todo isso acontecia conforme as comunicações entre o hàri e os espíritos de aruanã.

Assim acontecia na cultura dos nossos ancestrais. Os poderes de hàri eram muito grandes. Através dos conhecimentos dos nossos ancestrais, os homens realizavam suas caçadas e suas pescarias, tiravam os méis silvestres, todos de acordo com os pedidos de hàri. Quando aconteciam as caçadas de porcos queixadas, antes de irem atrás das caças, os homens faziam seu xiwè na casa dos homens pedindo que as caçadas nas matas ocorressem bem. Todos os homens que iam caçar levavam seus xiwè para a casa dos homens, que podiam ser alguns alimentos prontos, pedindo para não acontecer algo ruim nas caçadas. Depois das caçadas, no final do outro dia, os homens levavam novamente seus xiwè no pátio dos homens e faziam oferendas para os espíritos de ser humano (tori kuni) e também para os espíritos de aruanã. O chefe de ritual anuncia para fazer xiwè. Depois disso os homens comem os alimentos, as carnes de porcos queixadas.

\footnotetext{
${ }^{21}$ Há um processo em curso para demarcação da terra indígena Taego Awã para os Ava-Canoeiros - ver Rodrigues (2013).
} 


\section{A Fundação Nacional do Índio (FUNAI) e a Reunião dos Povos}

Quando começou a Fundação Nacional do Índio (FUNAI), criou-se um posto indígena na aldeia Kanõanõ. Foi então que povos de outras aldeias foram morar naquela aldeia, deixando seus lugares e passando a ficar reunidos numa única aldeia de Inỹ/Javaé. Mas ficou uma família na aldeia Barreira Branca (Tahakala [número 1 no mapa]) e também ficaram algumas famílias na aldeia Boto Velho (Tori-bero-ijò [número 54 no mapa]). Depois, entretanto, essas famílias mudaram-se também para aldeia Kanõanõ. Passaram algum tempo e voltaram de novo para seus lugares de origem.

Algumas lideranças não se adaptaram na aldeia Kanõanõ e por isso que voltaram para seus lugares. Mas outras aldeias não conseguiram voltar para seus locais de origem como aldeia Marani-Hawa, a aldeia Lòrèky, aldeia Imõtxi, aldeia Làràtxi, aldeia Wabe, aldeia Wari-Wari. Havia até uma aldeia dos Ixy Biawa ${ }^{22}$, na região de aldeia Wari-Wari, na margem do rio Javaés, que foram também morar na aldeia Kanõanõ.

No final da década de 1970 e na década seguinte, o retorno começou a ocorrer. No ano de 1979, a liderança Juraci Warasi Javaé mudou-se para região de Ikòròtòbò e fez uma aldeia com os seus parentes na atual aldeia São João (número 12 no mapa). Na década de 1980, uma família mudou-se para antiga aldeia Wari-Wari, porém não demorou muito e voltaram novamente para a aldeia Kanõanõ. Na mesma década, a família de João Tajuku Javaé mudou-se para a região da atual aldeia Cachoeirinha (Hèryrihiky [número 2 no mapa]). E na década de 1990, descendentes da antiga Wari-Wari fundaram a aldeia atual na margem do rio Javaés. Na mesma década foram desapropriados e indenizados os moradores não indígenas no Porto Piauí, que era um povoado existente na margem esquerda do rio Javaés, sendo inaugurada ali a aldeia Txuiri.

Os anos 2000 houve muitos conflitos entres os povos indígenas Inỹ/Javaé da Ilha do Bananal, o que causou os deslocamentos de algumas famílias que criaram muitas aldeias nas margens do rio Javaés. Esses conflitos ocorreram por questões políticas internas motivadas pelo contato com o mundo do capitalismo que afetou os modos tradicionais Iñ̃/Javaé de viver, provocando perda de contato até mesmo entre parentes próximos. A principal razão é que foram instalados arrendamentos de pastagens naturais no interior da Ilha do Bananal para pecuaristas da região. Tais arrendamentos eram feitos diretamente entre o pecuarista e a liderança de um determinado lugar. Com isso foram criadas diversas aldeias nas margens do rio Javaés, com a intenção de receber os benefícios de fazendeiros ${ }^{23}$.

Assim está acontecendo atualmente com o povo Inỹ/Javaé da Ilha do Bananal. Antes da chegada de não indígenas, os ancestrais viviam nos seus territórios com tranquilidade. Com as divisões de seus territórios sob domínio de cada aldeia, visando ao arrendamento das pastagens, a situação ficou muito difícil para os Javaé, porque os descendentes de cada região têm seus direitos nos seus lugares de origem. Por exemplo, na antiga aldeia Marani-Hawa, quase todos os Inỹ/Javaé são descendentes de ancestrais daquele lugar e se

\footnotetext{
22 Também conhecidos como Karajá-Xambioá, que vivem atualmente em terras demarcada nas margens do baixo Araguaia. Ver Giraldin (2002).

${ }^{23}$ Atualmente, esse arrendamento é feito diretamente com o Conselho das Organizações Indígenas do povo Javaé da Ilha do Bananal (Conjaba), que administra os recursos e repassa para as associações de cada aldeia.
} 
sentem com direitos sobre aquele território. De acordo com o ancião Xiari Javaé, morador da aldeia Wari-Wari que demonstra esse elo com o lugar de origem, "[...] a referida região é um lugar sagrado para seu povo, pois é um dos lugares de ascensão ao plano terrestre (Iny-Òlòna), local onde surgiu um dos ancestrais deste povo Tòlòra" (PIN, 2014, p. 44).

\section{Práticas Culturais no Passado e no Presente}

Os povos indígenas Inỹ/Javaé da Ilha do Bananal viviam com muita tranquilidade nas suas práticas culturais tradicionais nos tempos passados. Cada povo Inỹ/Javaé vivia em regiões diferentes e com seus rituais, suas músicas e as suas vidas cotidianas. Cada comunidade local tinha seu chefe de ritual (ixy-tyby), os seus iòlòs, seus compositores musicais (widu), seus lutadores (ijèsudu ou malua) e seus atletas. Ou seja, existiam as pessoas com suas capacidades específicas, fruto das suas preparações culturais e sociais.

A competição de luta corporal era muito praticada na cultura antiga dos povos Inỹ/Javaé da Ilha do Bananal. Quando chegavam os visitantes nas outras aldeias, já começavam as lutas (ijèsu), praticadas pelos malua (lutador). Mas também existiam atletas que alcançavam os animais na corrida e os matavam com as bordunas. Tinham competições de atletas chamadas de wyhy-raheto, sendo que o nome wyhy significa flecha e raheto é cocar. O nome da competição então refere-se ao cocar de flecha.

A competição dos Iwayrè-mahadu Karajá, como as lutas e as competições de atletismos, eram realizadas nas praias. Também os povos antigos competiam nos rituais de aruanãs. Uma dessas competições se dava entre cantores, para saber os que tinham as melhores vozes e avaliar seus conhecimentos das músicas. Também competiam nos rituais de iniciação de menino para a fase adulta, como com as músicas de worosy-tyhy, cujas várias músicas são executadas em ordem, com o começo (iòraru-na), meio (itya) e final (ikèsèna). Os pares de cantores cantavam desde a meia noite até as seis horas da manhã. Então, se um dos companheiros errava, a dupla perdia no quesito conhecimento das músicas. Assim, mesmo nos rituais havia competição.

Assim é na cultura tradicional do povo Inỹ/Javaé. Para isso, os povos antigos se preparavam com as plantas nativas chamadas de seseruty, que ficam nas margens do rio ou nos lagos. Os homens preparavam as plantas, tiravam as cascas e colocavam na água dentro de um coité (walu) para tomar. Essas plantas ardem muito e são amargas. Alguns jovens passavam três dias sem se alimentar e só tomavam seseruty e passavam pimentas no hetxi (ânus) para serem bem fortes e lutadores. Um dos preparativos era escarificar o corpo (as pernas, coxas, braços, peito e as costas) e depois passar a pimenta e, além disso, também tomavam os caldos grossos de pimentas sempre muito ardidos. E não era qualquer pessoa que riscava os corpos dos jovens em resguardo. Só alguém que era lutador, atleta ou trabalhador fazedor de roça e construtor de canoa que faziam, para poder transmitir suas forças ou habilidades para o jovem. À noite, o aprendiz de lutador treinava os movimentos da luta e depois ia para o rio onde passava a noite dentro da água. Colocava um tronco de uma árvore que não quebra nem cai fácil, como tronco de caraíba (Hatxukò) ou Hanotitira, nos quais se segurava dentro da água. Com isso, transmitia a dureza e flexibilidade da árvore para seu corpo. Esse tratamento também 
servia para ficarem com a voz boa e para ser lutador (ijèsidu), ou atleta, ou mesmo para ser bom trabalhador na vida cotidiana dos homens. Nesses processos, precisavam de muitas pimentas na preparação do corpo do ser humano na cultura dos povos Inỹ/Javaé. Essas plantas serviam para todos os momentos na vida dos homens nos tempos antigos.

As competições de atletas estão quase extintas há muitos anos e não são mais intensamente praticadas na cultura. Hoje em dia as novas gerações praticam mais futebol. Então nesse meio é que é demonstrado quem tem mais potência e habilidade de correr nos campos de futebol.

A luta corporal ainda existe na cultura dos povos Inỹ/Javaé. Quando há a realização de ritual de Hetohokỳ, os tios maternos de crianças que estão no rito de passagem competem com os worosy, os espíritos dos primos míticos Tabuhana e Ijòwyra, que sempre estão na casa dos homens.

As pessoas que eram lutadores (ijèsudu), os atletas (ijaradu) e os cantores das vozes boas (kumawi ou ikumawi, onde o nome kuma significa a voz, então ikumawi refere-se às pessoas que tem sua voz boa,) elas não podiam ter relações sexuais várias vezes numa mesma noite. O recomendado era fazer sexo na madrugada e depois se levantar logo cedo. E se não faziam isso, as forças e habilidades das pessoas diminuíam.

Também não podiam comer muito. Eles consumiam só as bebidas chamado de iwèru (calugi) produzida pela fermentação da mandioca e do milho. Eles sempre ficavam de jejum (inarèhè) e vomitavam (hylòi), quase todos os dias (solteiros, pela manhã, e casados no final da tarde). Tomavam os seseruty só para vomitar, o que era condição necessária para ter voz boa.

Os povos antigos passavam por processos fortes e rígidos de preparação do corpo. Hoje em dia os mais jovens não se interessam pelos conhecimentos e aprendizagem dos nossos antepassados. As novas gerações demonstram ter mais interesse na cultura ocidental, mas não aprenderam as formas de vida dos não indígenas. Hoje os jovens se interessam mais nas questões de aprendizagem da língua portuguesa e as comunidades incentivam mais as novas gerações para aprenderem a língua portuguesa.

Na cultura tradicional dos povos Inỹ/Javaé da Ilha do Bananal havia a roça tradicional (koworu), que o não indígena chama roça de toco. O primeiro plantio feito era semear melancia, milho, abóbora. Depois eram plantadas outras plantas como a rama de mandioca, mudas de banana, várias espécies de cará, amendoim, feijão andu, a batata-doce, cana e melão croá (sicana odorífica). As mulheres eram responsáveis pelo plantio da roça com as sementes, sendo que nas divisas entre as roças eram plantadas as sementes de urucum para demarcar as fronteiras. Nos cantos da roça era plantado açafrão. As tarefas e atividades masculinas no trabalho da roça era o plantio das sementes de milho, as ramas de mandiocas, os "olhos" de canas, as mudas de banana e as mudas de abacaxi. Os homens também faziam as limpezas das roças. Quando ocorria a primeira colheita de melancia e de milho, os sogros eram os primeiros a comer; depois os cunhados (labuna, sendo que o nome labu significa relação sexual do ponto de vista feminino ${ }^{24} \mathrm{e}$ na é o lugar). A mulher convidava seus primos para comer primeiro alimentos que seu esposo trouxe para a família, como um pagamento de serviço da noiva. Ajuntavam seus parentes, seus

${ }^{24}$ A relação sexual, do ponto de vista masculino, é hòo. 
tios e primos e a mulher os colocavam sentados em cima de uma esteira e colocava uma bacia de barro grande cheia de fatias de melancia. Então todos comiam na maior alegria e felicidade, com as pessoas rindo e brincando. Assim acontecia na cultura tradicional do povo Inỹ/Javaé. Ainda existia labuna na aldeia Kanõanõ, na década de 1970 e 1980.

Hoje em dia, as atividades culturais dos povos indígenas Inỹ/Javaé estão cada vez transformadas. Devido ao contato mais intenso com o mundo não indígena, as roças tradicionais quase não são praticadas atualmente. Os hábitos alimentares estão muito mudados, pois atualmente os alimentos vêm da cidade adquiridos em supermercados.

No passado, quando um rapaz não podia fazer a roça, ele só pescava e caçava. As tarefas de fazer a roça, pescar, caçar e carregar as lenhas eram partes de atividades do homem casado. O rapaz e a moça não podiam trabalhar igual aos casados. As moças faziam mais os enfeites e adornos, enquanto os jovens praticavam confeccionando mais os utensílios de casa, como fazer os cestos femininos (wèriri), ou então os bèhyra, cesto masculino para carregar as coisas das roças. Ele praticava fazer os abanos, as flechas, os arcos, uma lança ou cesto de homem, chamado warabahi, usado para guardar seus materiais de fazer as flechas, as penas de pássaros e os ferrões de peixes ${ }^{25}$ e os ossos de animais ${ }^{26}$, e um cesto só para guardar as coisas de mulher (lala) ou cesto para guardar coisas de bebê (tarihàna), como o óleo de babaçu, o óleo de tucum, o urucum e rezinas de alméscar. Essa resina é usada como adesivo para fixar penugens de pato e mergulhão nos corpos dos jovens em momentos rituais. Mas é usado também como remédio para diversos incômodos. A mistura de resina com óleo é passada no corpo e no cabelo quando há algum inchaço no corpo. Para bronquite e tosse forte, ferve-se uma mistura da resina com água e toma. As folhas e cascas servem para fazer banho para qualquer situação de febre ou qualquer outro incômodo.

A moça tinha como tarefas as atividades de fazer os enfeites e adornos, como os enfeites que são usados nas pernas (dekobutè), feitos de linha de algodão que amarra abaixo do joelho e tem uma linha apenas pendente na frente. As moças praticavam quando estavam na reclusão que ocorria na menarca. Elas praticavam fazer as esteiras e fiar algodão para fazer enfeites das pernas (kurawo), que são amarrados abaixo do joelho, mas cobrem toda a perna. Elas faziam também os enfeites usados nos braços (dexi) e treinavam fazer as pinturas corporais. Essas aprendizagens e conhecimentos de pinturas corporais eram destinadas para ambos os sexos. Tanto os homens como as mulheres precisavam aprender os conhecimentos de pinturas.

\section{Considerações Finais}

O que causa atualmente esse processo de transformação cultural? Devido certamente ao contato mais intenso com o mundo não indígena. Em decorrência da depopulação ocorrida desde o contato, no século XVIII, mas intensificada no início do século XX,

\footnotetext{
${ }^{25}$ Como esporão de arraia ou de surubim, usados como ponta de flechas para matar animais como onça, veado, porco queixada.

26 Como osso do macaco guariba para furar lábios dos meninos e osso de macaco prego para fazer ponta de flechas para matar peixes, tartaruga. Osso de onça era usado para fazer ponta de lança para guerra ou para matar animais, como porco queixada.
} 
diversos rituais tiveram retração. Assim, na década de 1970, houve retomada da realização de rituais como o de iniciação de criança menino para a fase adulta chamado Hetohokỳ. Logo após começou o ritual de Iwèruhuky em homenagem aos iolós, sendo realizados na aldeia Kanõanõ. Há muito tempo que os rituais não eram realizados porque o chefe de ritual havia falecido na primeira aldeia Kanõanõ, ao lado direito na margem do rio Javaés. A partir da morte do chefe de ritual, nunca mais foi escolhido um substituto até que, no final dos anos de 1970, José Wèrèumari Javaé escolheu seu primo Kumahira Javaé como um novo chefe de ritual (ixy-tyby). Foi então que os rituais voltaram a ser praticados na cultura dos povos Inỹ/Javaé. Quando foram realizados os rituais, quase todos homens participaram do Hetohokỳ. Foi muito bem respeitado e feito de forma correta pelo chefe do ritual. E logo depois teve a realização de ritual Iwèruhuky, com grande participação dos homens e das mulheres. A última realização de Iwèruhuky foi nos anos de 1980. Depois, logo meu tio ${ }^{27}$ Kumahira Javaé faleceu. Depois do falecimento dele, nunca mais foi realizado o ritual de Iwèruhuky.

O ritual de Hetohokỳ ainda existe na cultura dos povos Inỹ/Javaé, mas é praticado com mudanças e os jovens têm pouco interesse em participar, seja nas danças ou nas músicas, de acordo com as regras e formas corretas de serem praticadas.

Os rituais de espíritos de aruanã eram muito desenvolvidos nas comunidades. Quando havia a brincadeira de espíritos de aruanã, as pessoas das comunidades participavam, sejam os homens ou as mulheres. Era muita alegria. Todos se divertiam, as mulheres dançavam. Quando acontecia a brincadeira de espíritos de aruanã, aconteciam também as brincadeiras maiores, como a brincadeira de kobiku (os peixes assados) e a brincadeira de iwodudu (tipo de pastel, com os peixes enrolados de massa de mandioca). Então, quando aconteciam essas brincadeiras de espíritos de aruanã, as comunidades ficavam alegres, os espíritos de aruanãs dançavam as noites todas. Eu presenciei ${ }^{28}$ essas brincadeiras na aldeia Kanõanõ nos anos de 1970. A cultura tradicional era bem forte, mas já havia começado a prática do futebol. Tinha competição com os times da Fundação Bradesco e era só com esses times que os povos indígenas Inỹ/Javaé competiam.

O que está acontecendo atualmente não existia na cultura do povo Inỹ/Javaé. Em algumas festas de espíritos de aruanã, eles só dançam alguns momentos apenas para mostrar para as mídias. As lideranças orientam para realizar as danças de espíritos de aruanã como se fosse uma brincadeira qualquer, sendo que as novas gerações, vendo isso, estão aprendendo dessa forma. Na tradição, os espíritos de aruanãs só dançam quando tem as festas nas aldeias, não dançando em outro momento qualquer. Então para os mais velhos da comunidade não está havendo o respeito com seus conhecimentos na cultura tradicional. Assim está a vida dos povos Inỹ/Javaé atualmente.

Na cultura do povo Inỹ/Javaé houve muitas mudanças, sendo que algumas são bastante radicais em relação ao passado. As datas comemorativas do calendário tori no meio da convivência nos povos atuais estão sendo muito influenciadas pelas datas comemorativas das festas pátrias como a Independência do Brasil, no dia 7 de setembro; Dia da Criança, em 12 de outubro; Dia do Índio, no dia 19 de abril; festas juninas e algumas festas como as datas de aniversários de algum filho de um cacique.

\footnotetext{
27 Do ponto de vista de Ricardo Tewaxi Javaé, coautor deste artigo.

28 Idem.
} 
O maior encontro dos povos indígenas da Ilha do Bananal ocorre na data de Independências do Brasil, o dia Sete de Setembro. O cacique da aldeia Kanõanõ convida todos os povos indígenas da Ilha do Bananal, como os Iwayrè-mahadu (Karajá) de todas as regiões do Araguaia e também convidam outros povos, como os Xerente (Iny-ròdumahadu) e os povos Ixybiawa Karajá (Xambioa), o povo Wou-mahadu (Tapirapé de Mato Grosso) e também convidam os não indígenas. Assim está acontecendo na vida dos povos indígenas Inỹ/Javaé. Nas festas dessas datas comemorativas, a cada ano, mais os caciques competem entre si com as festas que organizam, bem como com os cantores não indígenas que cobram altos valores de cachê.

O lado bom dessas festividades é que, nesses dias festivos, as lideranças se encontram ou se reúnem e algumas pessoas aproveitam para se encontrar com seus parentes no meio das festas. Além disso, as pessoas interagem com os outros povos que são convidados.

Quando, nas décadas de 1970 a 1980, a FUNAI era responsável pelos arrendamentos de pastagem nativas nas Ilha do Bananal, os indígenas Inỹ/Javaé não sabiam que existiam esses arrendamentos e não administravam os recursos financeiros que se originavam. A FUNAI fornecia os transportes para cada povo indígena, como o trator, o carro, a canoa de alumínio, motores de popas 25 Hp e também foram instaladas umas serrarias nas comunidades, além dos projetos de lavouras havendo também ferramentas e os gados nas comunidades. Com o passar dos tempos, a FUNAI deixou de administrar esses recursos e também não fornece mais os objetos para as comunidades indígenas. Hoje tudo está a cargo das lideranças atuais, que administram os recursos oriundos do arrendamento de pastagens. Mas nem sempre esses recursos financeiros são utilizados em benefício das coletividades.

Acreditamos que, assim como a maioria dos povos indígenas no Brasil, os Inỹ/Javaé vivem nesse dilema de ter que navegar com um pé em cada canoa. Uma é a da tradição, com sua língua, seus rituais e a forma de construir, ver e viver o mundo. Outra é a língua portuguesa, a escola, os empregos remunerados, a monetarização das relações, as cidades e as manifestações culturais dos não indígenas. Equilibrar-se, resilientemente, nessas duas canoas é o desafio que este artigo procurou salientar.

\section{Referências}

BASSO, E. O que podemos aprender do discurso Kalapalo sobre a "história Kalapalo. In: FRAnCHetTO, B.; HeCKenberger, M. (org.). Os Povos do Alto Xingu: História e Cultura. Rio de Janeiro, Editora da UFRJ, 2000. p. 293-307.

GIRALDIN, O. Catequese e civilização. Os capuchinhos "entre" os "selvagens" do Araguaia e Tocantins. Boletim do Museu Paraense Emílio Goeldi, série Antropologia, [s.l.], v. 18, n. 2 , 2002.

INGOLD, T. The Perception of the Environment: Essays on livelihood, dwelling and skill. London; New York: Routledge, 2000.

JAVAÉ, Ricardo Tewaxi. Nas águas do rio Javaés. Histórias, cosmologia e meio ambiente. 2019, 146f. Dissertação (Mestrado) - Universidade Federal do Tocantins, Palmas, 2019.

JAVAÉ, Ricardo Tewaxi e GIRALDIN, Odair. Rede de histórias dos povos que deram origem ao povo Inỹ/Javaé. R@U - Revista de Antropologia da UFSCAR, São Carlos, v. 11, n. 2, jul.dez. p. 51-68, 2019. 
KARAJÁ, J. H. As madeiras e seus usos no universo sócio-cultural do povo Inỹ. 2015. 83p. Dissertação (Mestrado) - Universidade Federal do Tocantins, Palmas, 2015.

LITTLE, Paul E. Territórios sociais e povos tradicionais no Brasil: por uma antropologia da territorialidade. Anuário Antropológico/2002-2003. Rio de Janeiro: Tempo Brasileiro, 2003. p. 251-290. Disponível em: https://www.academia.edu/7521331/Reservas_Extrativistas_de Pol\%C3\%ADtica_P\%C3\%BAblica_\%C3\%A0_Pol\%C3\%ADtica_de_Ressentimento. Acesso em: 12 nov. 2021.

MORI, Robert. Os aldeamentos indígenas no Caminho dos Goiases: guerra e etnogênese no "Sertão do Gentio Cayapó" (Sertão da Farinha Podre) - séculos XVIII e XIX. 2015. 232p. Dissertação (Mestrado) - Universidade Federal de Uberlândia, Minas Gerais, 2015.

PEDROSO, D. M. R. Ava-Canoeiro: A história do povo invisível, séculos XVIII e XIX. 1992. 348p. Dissertação (Mestrado em história das sociedades agrárias) - Universidade Federal de Goiás, Instituto de Ciências Humanas e Letras, Goiânia, 1992.

PIN, A. E. História do povo Javaé (Iny) e sua relação com as políticas indigenistas: da colonização ao Estado brasileiro (1775-1960). 2014. 161p. Dissertação (Mestrado) Universidade Federal de Goiás, Goiânia, 2014.

RODRIGUeS, P. de M. O Povo do Meio: Tempo, Cosmo e Gênero entre os Javaé da Ilha do Bananal. 1993. 438p. Dissertação (Mestrado) - Universidade de Brasília, Brasília, DF, 1993.

RODRIGUES, P. de M. A caminhada de Tanỹxiwè: uma teoria Javaé da História. 2008. 953p. Tese (Doutorado) - Universidade de Chicago, Chicago (Illinois), 2008.

RODRIGUES, P. a de M. Os Avá-Canoeiro do Araguaia e o tempo do cativeiro. Anuário Antropológico [on-line], v. I, 2013. Disponível em: http://journals.openedition.org/aa/402. Acesso em: 18 set. 2019. DOI: 10.4000/aa.402, 2013. (Posto on-line no dia $1^{\circ}$ outubro 2013).

TUAN, Yi- Fu. Espaço e Lugar: a perspectiva da experiência. São Paulo: DIFEL, 1983.

\section{Odair Giraldin}

Doutor em Ciências Sociais pela Unicamp. Professor titular da Universidade Federal do Tocantins. Endereço profissional: Universidade Federal do Tocantins, Curso de História, Porto Nacional, TO. CEP: 77500-000.

E-mail: giraldin@uft.edu.br

ORCID: https://orcid.org/0000-0001-6230-493X

\section{Ricardo Tewaxi Javaé}

Mestre em Ciências Ambientais pela Universidade Federal do Tocantins e professor da Escola Indígena Tainá.

Endereço profissional: Escola Indígena Tainá, Ilha do Bananal, Formoso do Araguaia, TO. CEP: 77470-000. E-mail: ricatewa@gmail.com

ORCID: https://orcid.org/0000-0002-4792-1216

\section{Como referenciar este artigo:}

GIRALDIN, Odair; JAVAÉ, Ricardo Tewaxi. Espaço, Tempo e Narrativas: reflexões sobre a cultura Inỹ/Javaé, Ilha do Bananal, Tocantins, Brasil. Ilha - Revista de Antropologia, Florianópolis, v. 24, n. 1, e78338, p. 162-189, janeiro de 2022. 